\title{
DEPOLIMERISASI KARET ALAM SECARA MEKANIS UNTUK BAHAN ADITIF ASPAL
}

\author{
Mechanically Depolimerization of Natural Rubber for Asphalt Additive Material \\ Henry PRASTANTO \\ Pusat Penelitian Karet, \\ Jalan Salak No 1 Bogor 16151 \\ Email : hprastanto@yahoo.com
}

Diterima : 10 Februari 2014 / Direvisi : 25 Maret 2014 / Disetujui :12 April 2014

\begin{abstract}
Natural rubber is a potential natural polymer for asphalt additive material to subtitute imported sinthetics polymer, but in high viscosity at dry form is difficult to mix with asphalt.This research was to study the effect of depolimerization of natural rubber to the mixing process, melting point and penetration rate of asphalt. The depolimerization process was carried out by using laboratory two roll-mill with diameter $14 \mathrm{~cm}$ and length $35 \mathrm{~cm}$. Depolimerized natural rubber was added in to asphalt of 3\%, 5\% and 7\% by weight of asphalt at $160^{\circ} \mathrm{C}$ then compared with unload asphalt as control, followed by testing of melting point and penetration rate of samples. The results showed that depolimerization for 24 minutes decreased molecular weight indicated by decreasing of Mooney viscosity, from 58,7 became 6,7 ML $(1+4) 100^{\circ} \mathrm{C}$. Mechanically depolimerized natural rubber for 24 minutes with $3 \%$ concentration in asphalt decreased mixing time form 660 minutes to 50 minutes and melting point increased from $51^{\circ} \mathrm{C}$ became $56,5^{\circ} \mathrm{C}$, while the penetration rate decreased from $55 \mathrm{dmm}$ became $40 \mathrm{dmm}$.
\end{abstract}

Keywords: Mechanically depolimerization, dry rubber, asphalt, melting point, penetration

\section{Abstrak}

Karet alam yang merupakan polimer alami berpotensi digunakan sebagai bahan aditif aspal pengganti polimer sintetis impor, namun viskositas yang tinggi pada karet alam fasa padatan tergolong sulit untuk dicampurkan ke dalam aspal. Penelitian bertujuan untuk mengetahui pengaruh depolimerisasi karet alam terhadap proses pencampuran, titik lembek dan penetrasi aspal. Proses depolimerisasi dilakukan dengan menggunakan open mill skala laboratorium dengan diameter $14 \mathrm{~cm}$ dan panjang $35 \mathrm{~cm}$. Karet terdepolimerisasi yang ditambahkan ke dalam aspal sebanyak 3\%, 5\%, dan 7\% dengan sampel kontrol adalah aspal murni, dilanjutkan dengan pengujian titik lembek dan penetrasi sampel. Hasil penelitian menunjukkan proses depolimerisasi secara mekanis selama 24 menit dapat menurunkan berat molekul karet alam yang ditandai dengan penurunan viskositas Mooney karet dari 58,7 menjadi 6,7 $\left.\mathrm{ML}(1+4) 100^{\circ} \mathrm{C}\right)$. Karet alam terdepolimerisasi secara mekanis selama 24 menit dengan konsentrasi karet dalam aspal 3\% dapat menurunkan waktu pencampuran dari 660 menit menjadi 50 menit dan titik lembek aspal modifikasi yang dihasilkan bertambah dari $51^{\circ} \mathrm{C}$ menjadi $56,5^{\circ} \mathrm{C}$, sedangkan penetrasi aspal polimer yang dihasilkan turun dari $55 \mathrm{dmm}$ menjadi $40 \mathrm{dmm}$.

Kata kunci: Depolimerisasi mekanis, karet mentah padat, aspal, titik lembek, penetrasi

\section{PENDAHULUAN}

Indonesia adalah negara penghasil karet alam terbesar ke dua di dunia setelah Thailand dengan produksi pada tahun 2012 mencapai 3,04 juta ton per tahun (Ditjenbun, 2013). Secara Internasional pada tahun 2012 terjadi surplus karet alam sebesar 296.000 ton (IRSG, 2013). Mayoritas dari produksi karet alam Indonesia diekspor dalam bentuk karet mentah utamanya sebagai SIR 20. Konsumsi karet alam saat ini didominasi untuk pemenuhan kebutuhan pembuatan ban kendaraan. Untuk meningkatkan konsumsi karet alam domestik perlu upaya diversifikasi produk antara lain untuk aditif aspal.

Aspal polimer adalah aspal keras yang dimodifikasi dengan polimer. Aspal polimer terdiri atas aspal plastomer dan elastomer. Contoh plastomer (plastik) antara lain polypropylene dan polyethylene, sedangkan elastomer antara lain aspal karet 
alam dan styrene butadiene styrene (SBS) (SNI 6749:2008). Penggunaan polimer sintetis telah dilakukan untuk meningkatkan mutu aspal. Namun bahan tersebut perlu diimpor, sehingga tidak memberi nilai tambah bagi produk dalam negeri dan sangat tergantung dari produsen di luar negeri.

Modifikasi aspal dengan karet merupakan sistem dua campuran yang mengandung karet dan aspal yang berfungsi untuk meningkatkan kinerja aspal antara lain mengurangi deformasi pada perkerasan, meningkatkan ketahanan terhadap retak dan meningkatkan kelekatan aspal terhadap aggregat (Suroso, 2007). Karet alam sebagai polimer alami berpotensi digunakan sebagai aditif aspal pengganti polimer sintetis impor. Penelitian tentang aspal karet telah dilakukan dengan menggunakan beberapa jenis karet. Misalnya seperti yang dilakukan oleh Suroso (2007) yang menggunakan lateks karet alam pekat dan karet sintetis. Departemen Pekerjaan Umum (1999) sudah menerbitkan petunjuk pembuatan campuran aspal dan lateks pekat berdasarkan hasil penelitian terdahulu.

Masalah yang dihadapi dalam pembuatan aspal karet dengan bahan aditif berupa lateks pekat adalah adanya buih dan pelepasan gas amoniak. Berdasarkan pengalaman operator di lapangan kondisi ini dapat membahayakan bagi pekerja. Di samping itu apabila karet alam yang digunakan berupa lateks pekat maka pemakaiannya tidak dapat mengatasi masalah harga karet apabila terjadi kelebihan pasokan karet remah.

Pemakaian karet mentah yang berupa padatan baik itu karet remah Standard Indonesian Rubber (SIR), Ribbed Smoked Sheet (RSS) dan krep apabila langsung digunakan sebagai aditif aspal maka akan membutuhkan waktu pencampuran yang sangat lama dan suhu yang lebih tinggi sehingga kurang diminati karena pada karet tersebut rantai molekul karet masih sangat panjang. Masalah ini dapat diatasi dengan memperlakukan teknik depolimerisasi terhadap karet alam. Depolimerisasi adalah proses pemutusan rantai panjang molekul polimer menjadi rantai molekul yang lebih pendek. Dalam proses pembuatan kompon karet dikenal tahap mastikasi, yaitu proses penggilingan karet alam dalam open mill yang bertujuan untuk memutuskan rantai molekul karet alam sehingga menjadi lebih lunak. Menurut Staudinger dalam Bateman (1963) mastikasi dapat menurunkan berat molekul karet hingga sepersepuluh dari berat molekul karet semula sekitar $10^{6}$. Penurunan berat molekul ini secara bersamaan disertai dengan penurunan viskositas Mooney karet. Dengan penurunan viskositas Mooney diharapkan karet menjadi lebih mudah dicampurkan dengan aspal.

Penelitian ini bertujuan untuk mempelajari pengaruh depolimerisasi terhadap penurunan viskositas Mooney karet, kemudahan pencampuran serta titik lembek dan penetrasi aspal karet yang dihasilkan.

\section{BAHAN DAN METODE}

Penelitian telah dlaksanakan di Pusat Penelitian Karet pada periode bulan April hingga Juli 2010. Bahan utama yang digunakan dalam penelitian ini adalah karet alam berupa karet remah SIR 20 dan aspal penetrasi 60. Bahan pembantu lainnya adalah peptizer karet dan hidroksilamin netral sulfat (HNS). Peralatan utama untuk depolimerisasi mekanis adalah open mill dengan kapasitas $1 \mathrm{~kg}$. Proses pencampuran aspal dan karet digunakan pemanas listrik, thermostat dan mixer.

Penelitian dilakukan dalam tiga tahapan yaitu depolimerisasi karet alam secara mekanis, pencampuran karet alam terdepolimerisasi dengan aspal dan pengujian aspal karet hasil pencampuran. Sebelum depolimerisasi, karet alam dikarakterisasi sifat kimianya meliputi viskositas Mooney, plastisitas awal (Po) dan plasticity retention index (PRI).

Depolimerisasi karet alam secara mekanis pada suhu sekitar $60^{\circ} \mathrm{C}$, dilakukan dengan penggilingan karet dalam open mill bersamaan dengan peptizer $2 \% \mathrm{~b} / \mathrm{b}$ terhadap berat karet untuk mempercepat pemutusan rantai molekul karet. Lama penggilingan divariasikan selama 8, 16 dan 24 menit dan dan pada akhir penggilingan ditambahkan HNS sebanyak 1\% untuk mencegah adanya kenaikan viskositas Mooney karet alam terdepolimerisasi selama penyimpanan. 
Karet hasil penggilingan kemudian diukur viskositas Mooneynya. Setiap sampel karet hasil penggilingan kemudian dicampurkan ke dalam aspal panas pada suhu $160^{\circ} \mathrm{C}$. Konsentrasi karet dalam aspal divariasikan sebesar 3\%, 5\% dan $7 \%$ b/b terhadap berat aspal dan sebagai pembanding digunakan aspal murni. Sampel didinginkan dan diuji sifat yang terpenting yaitu titik lembek dan penetrasinya sesuai dengan SNI 06-2434-1991.

\section{HASIL DAN PEMBAHASAN}

Viskositas Mooney karet, Po dan PRI memiliki pengaruh yang besar terhadap kecepatan pencampuran dan sifat fisik aspal. Hasil uji karakteristik karet dengan menggunakan alat Mooney Viscosmeter dan Plastimeter dapat dilihat pada Tabel 1.

Sifat karet yang digunakan dalam penelitian ini yaitu Po dan PRI ternyata memenuhi spesifikasi SIR 20 bahkan memenuhi kriteria SIR 10. Sedangkan untuk viskositas Mooney tidak menjadi persyaratan dalam SIR 20 maupun SIR 10. Meskipun demikian karena viskositas Mooney karet sebanding dengan berat molekul karet alam maka dalam penelitian ini menjadi penting dan digunakan sebagai patokan dalam menentukan sifat karet.

Depolimerisasi karet secara mekanis dapat menurunkan berat molekul karet alam yang ditandai dengan penurunan viskositas Mooney karet. Depolimerisasi secara mekanis dilakukan dengan proses penggilingan dengan open mill yang dikenal juga dengan proses mastikasi. Pada penelitian ini mastikasi dilakukan dalam waktu yang lebih lama dibandingkan dengan proses mastikasi yang umum dilakukan pada pembuatan kompon karet. Depolimerisasi atau mastikasi mengakibatkan karet menjadi lebih plastis dibandingkan dengan sebelum mastikasi. Semakin lama karet digiling atau diberi perlakuan mastikasi, maka karet akan menjadi semakin plastis dan nilai viskositas Mooney karet semakin menurun. Mastikasi dapat dilakukan tanpa ataupun dengan peptizer, namun penambahan peptizer dapat membantu mempercepat pemutusan rantai molekul karet. Penurunan viskositas Mooney karet ini tidak berbeda dengan penelitian Prastanto dan Alfa (2005) tentang pembuatan sealer pendingin dari karet alam. Nilai viskositas Mooney karet dalam penelitian ini dapat disajikan pada Gambar 1 berikut.

Konsentrasi karet dalam aspal mempengaruhi lamanya waktu pencampuran. Semakin tinggi konsentrasi karet dalam aspal, maka akan semakin lama waktu yang dibutuhkan aspal dan karet untuk bercampur hingga homogen. Begitu juga dengan berat molekul yang dapat digambarkan dengan besarnya nilai viskositas Mooney karet. Semakin tinggi viskositas Mooney maka waktu pencampuran juga semakin lama. Berat molekul dan viskositas Mooney yang tinggi menyebabkan karet menjadi keras sehingga susah terlarut dalam aspal. Grafik hubungan waktu pencampuran dengan jenis karet yang dicampurkan berdasarkan waktu giling dapat dilihat pada Gambar 2 berikut.

Berdasarkan hasil penelitian terlihat bahwa kecepatan pencampuran karet alam yang memiliki viskositas Mooney 6,7 ML

Tabel 1. Karakteristik sampel karet alam

Table 1. Characteristics of natural rubber sample

\begin{tabular}{lcc}
\multicolumn{1}{c}{$\begin{array}{c}\text { Parameter uji } \\
\text { Testing parameter }\end{array}$} & $\begin{array}{c}\text { Hasil uji } \\
\text { Test result }\end{array}$ & $\begin{array}{c}\text { SNI 06-1903-2011 } \\
\text { untuk SIR 20 } \\
\text { for SIR 20 }\end{array}$ \\
\hline $\begin{array}{l}\text { Viskositas Mooney } \\
\text { Mooney Viscosity }\end{array}$ & 58,7 & - \\
$\begin{array}{l}\text { Plastisitas awal (Po) } \\
\text { Plasticity before ageing (Po) }\end{array}$ & 31,0 & Min. 30 \\
$\begin{array}{l}\text { Plastisitas akhir (Pa) } \\
\text { Plasticity after ageing (Pa) }\end{array}$ & 17 & - \\
$\begin{array}{l}\text { Indeks Ketahanan Plastisitas } \\
\text { Plasticity Retention Index (PRI) }\end{array}$ & 54,8 & Min.40 \\
\hline
\end{tabular}




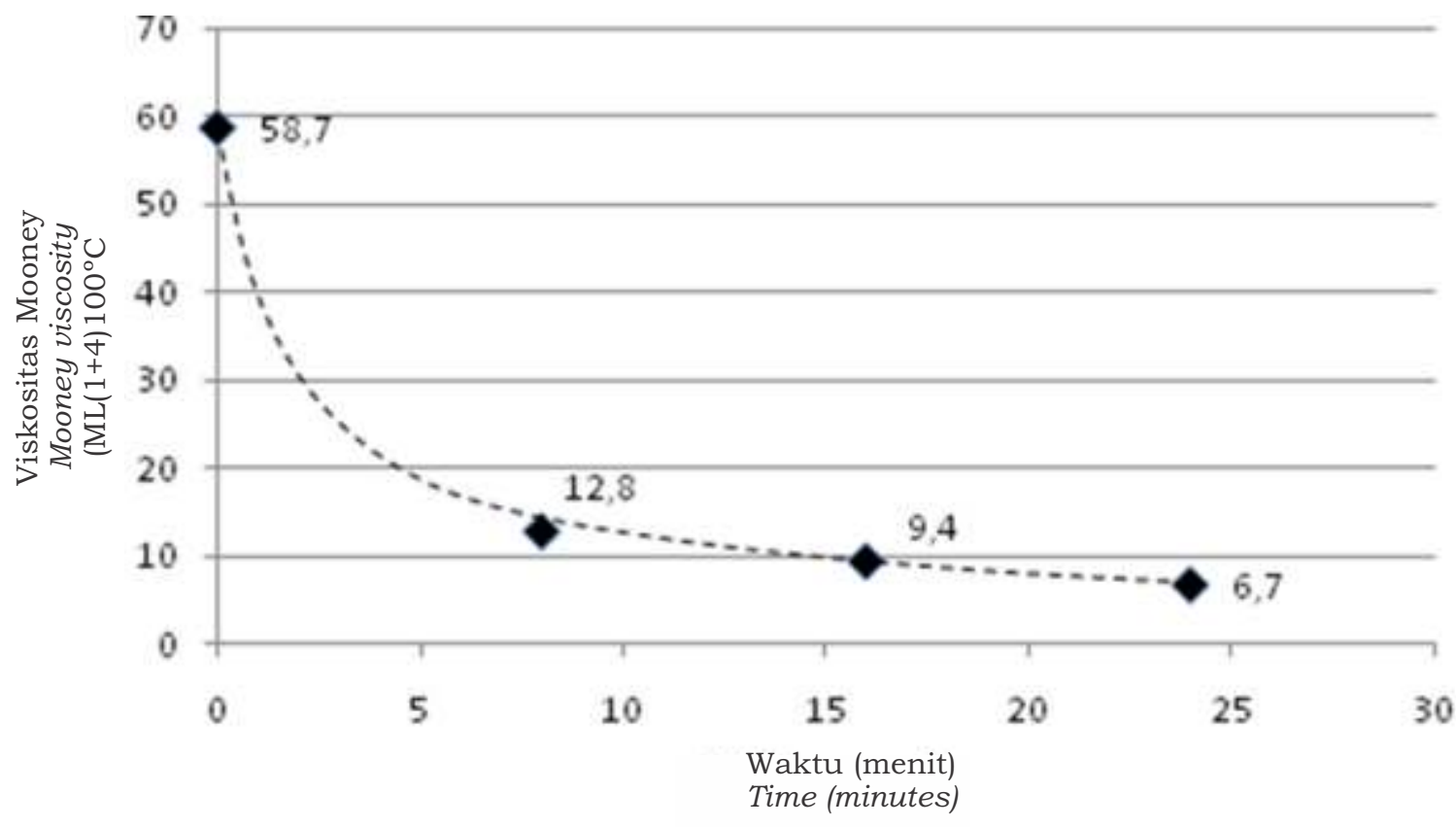

Gambar 1. Viskositas Mooney karet alam terdepolimerisasi Figure 1. Mooney viscosity of depolimerized natural rubber

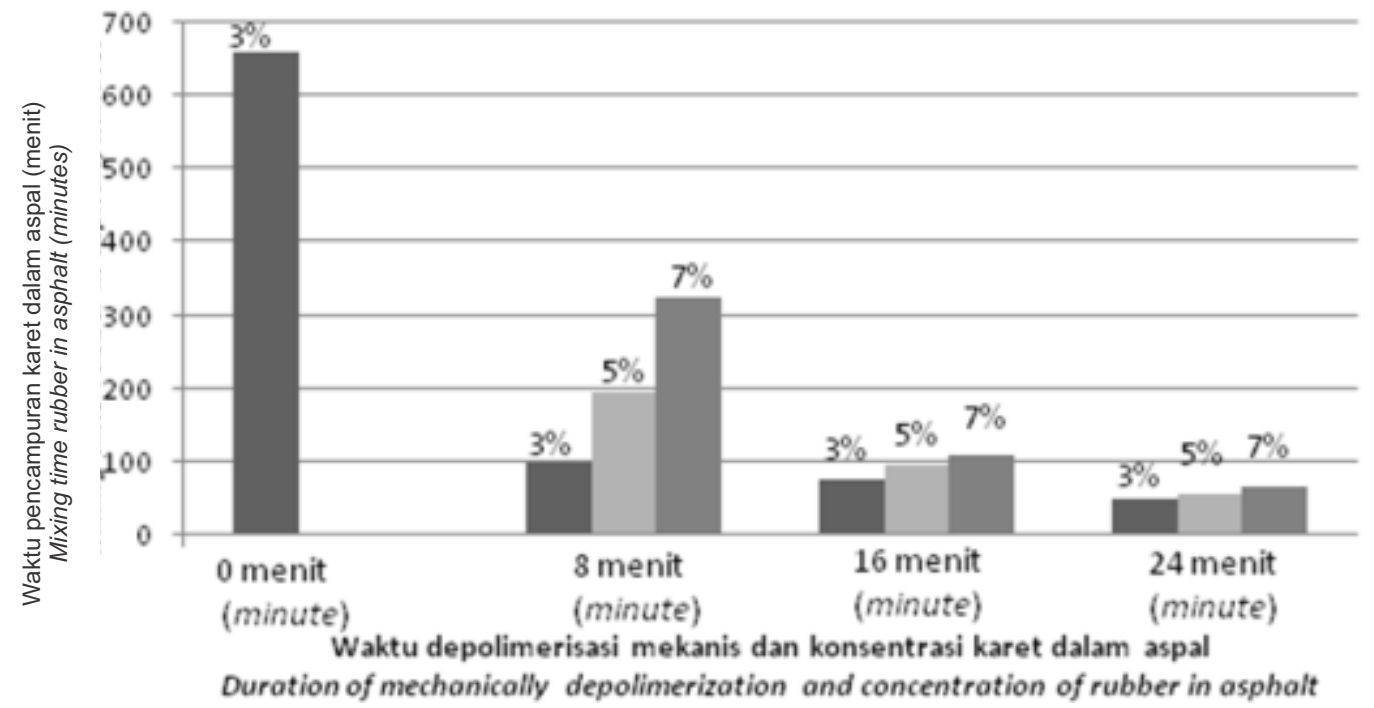

Gambar 2. Proses pencampuran karet alam terdepolimerisasi di dalam aspal Figure 2. Mixing process of depolimerized natural rubber in asphalt 
$(1+4) 100^{\circ} \mathrm{C}, 13 \mathrm{kali}$ lebih cepat tercampur dibandingkan dengan karet alam yang memiliki viskositas Mooney 58,7 ML (1+4) $100^{\circ} \mathrm{C}$, sehingga depolimerisasi karet alam secara mekanis ini efektif mempercepat kelarutan karet dalam aspal.

Pengujian aspal karet dilakukan terhadap 2 parameter utama pengujian aspal polimer, yaitu titik lembek dan penetrasi. Pengujian titik lembek aspal karet dilakukan untuk menentukan ketahanan aspal terhadap deformasi permanen. Titik lembek merupakan pendekatan utama selain penetrasi aspal untuk mengklasifikasikan kelas dan kualitas aspal untuk perkerasan jalan.

Proses modifikasi aspal dengan penambahan bahan aditif berupa karet remah terdepolimerisasi dinyatakan berhasil apabila nilai titik lembek aspal modifikasi lebih tinggi daripada nilai titik lembek kontrol (aspal penetrasi 60), yaitu $51^{\circ} \mathrm{C}$ dan memenuhi persyaratan SNI 6749:2008 untuk aspal polimer, yaitu $54^{\circ} \mathrm{C}$. Nilai titik lembek aspal beraditif karet dan aspal tanpa aditif karet dapat dilihat dan dibandingkan pada Gambar 3.

Dari Gambar 3 dapat dilihat bahwa nilai titik lembek aspal modifikasi meningkat seiring dengan meningkatnya konsentrasi karet yang ditambahkan ke dalam aspal.
Pada konsentrasi karet terhadap aspal 0\% (kontrol) yang berupa aspal penetrasi 60, nilai titik lembek yang didapatkan adalah sebesar $51^{\circ} \mathrm{C}$. Titik lembek aspal modifikasi berada pada kisaran nilai $53^{\circ} \mathrm{C}$ sampai dengan $57^{\circ} \mathrm{C}$. Hal ini menunjukkan bahwa penambahan karet remah terdepolimerisasi ke dalam aspal telah berhasil membuat titik lembek aspal menjadi lebih tinggi dari titik lembek kontrol. Dari data tersebut terlihat bahwa tidak semua sampel memenuhi persyaratan nilai titik lembek aspal polimer.

Uji penetrasi juga merupakan uji standar yang biasa dilakukan untuk mengklasifikasikan kelas dan kualitas aspal untuk perkerasan jalan. Proses penambahan karet alam ke dalam aspal dinyatakan berhasil apabila nilai penetrasi aspal modifikasi lebih rendah dari nilai penetrasi kontrol yaitu aspal penetrasi 60/70 serta memenuhi standar aspal polimer jenis elastomer yaitu 50-75 dmm (SNI 6749:2008). Nilai penetrasi sampel pada tiap konsentrasi yang berbeda dapat dilihat pada Gambar 4 .

Dari Gambar 4 dapat dilihat bahwa penetrasi aspal yang dihasilkan berkisar antara 41 sampai $55 \mathrm{dmm}$. Penambahan karet alam yang telah didepolimerisasi ke dalam aspal telah berhasil meningkatkan kekerasan aspal dilihat dari semakin menurunnya nilai penetrasi. Pada sampel yang telah ditambahkan karet alam dengan

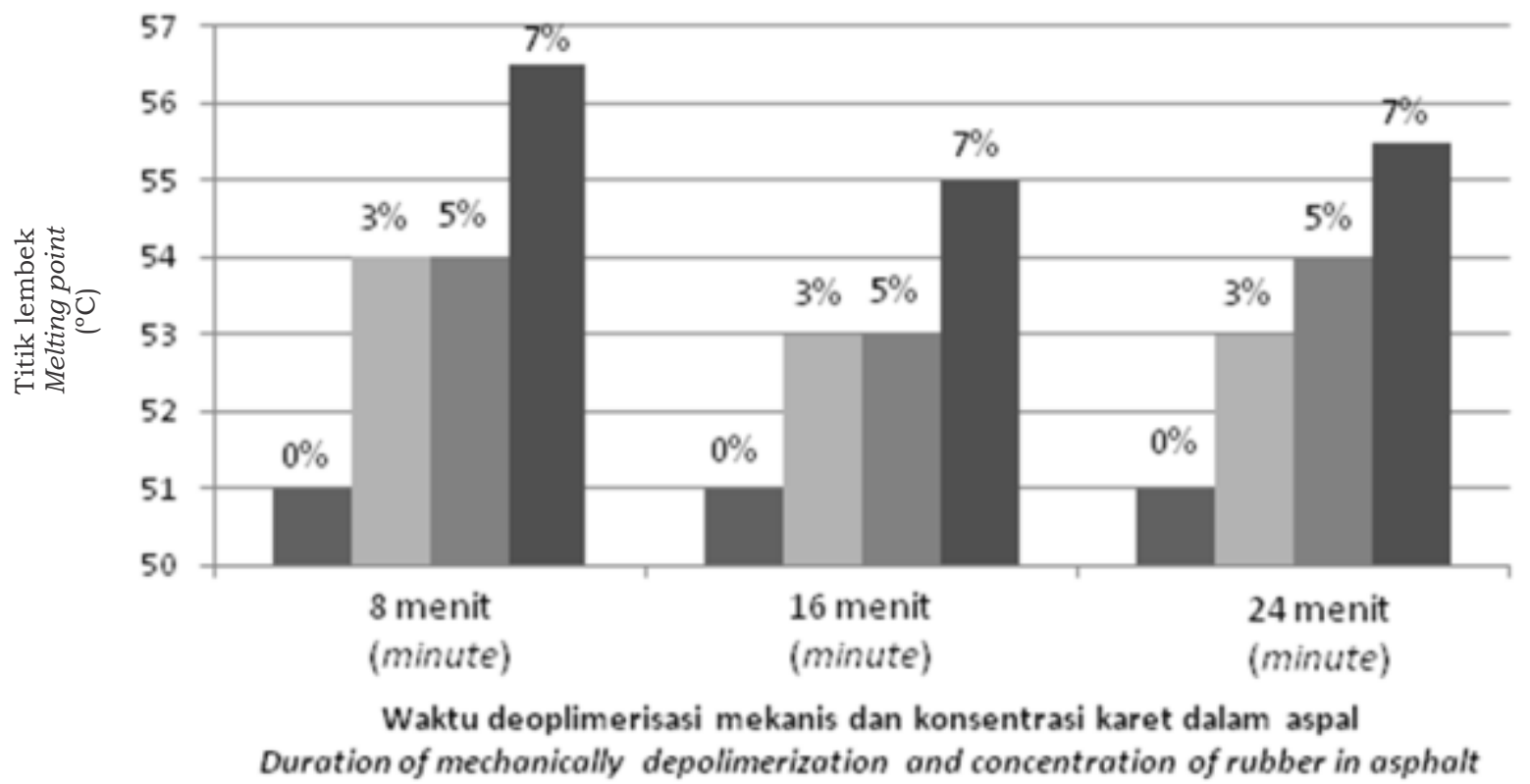

Gambar 3. Titik lembek sampel pada berbagai perlakuan

Figure 3. Melting point of samples at various treatments 


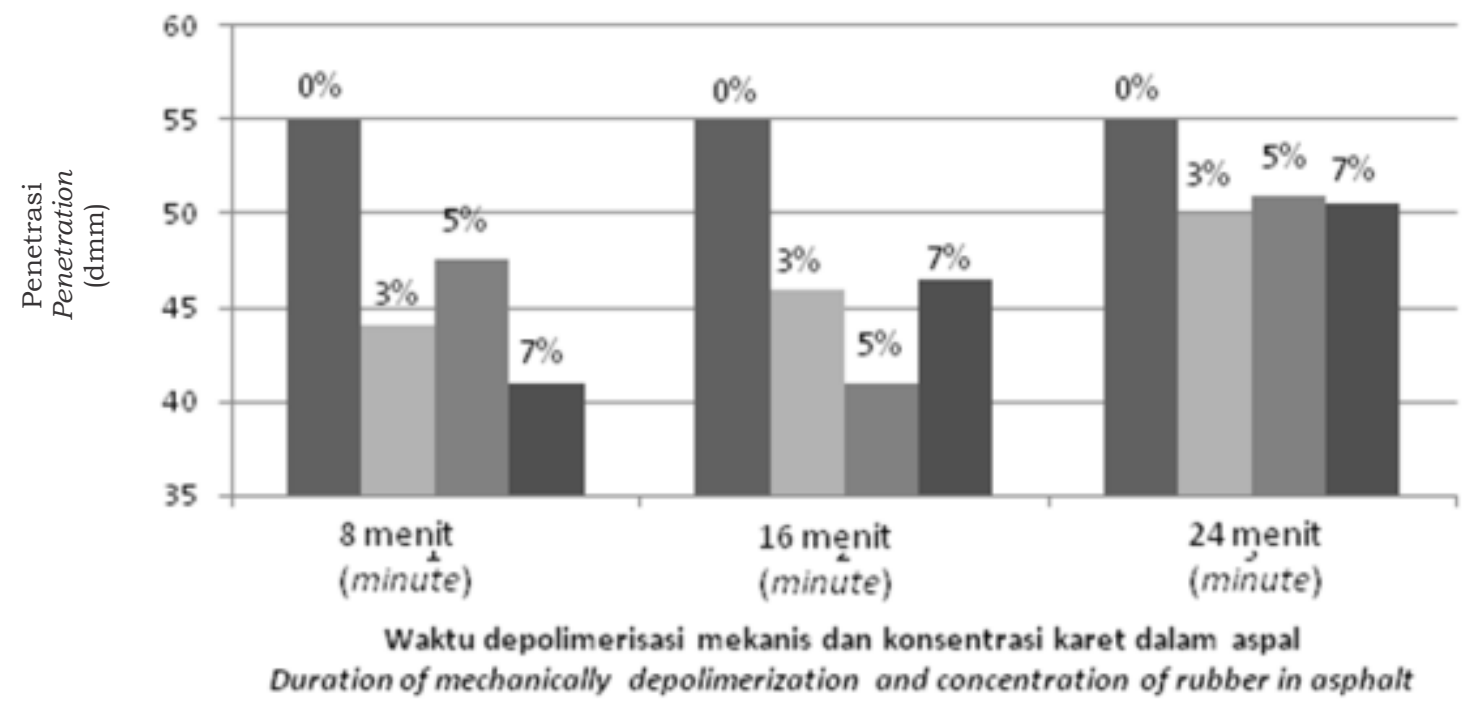

Gambar 4. Laju penetrasi sampel pada berbagai perlakuan Figure 4. Penetration rate of samples at various treatment

viskositas Mooney terrendah secara umum memiliki tingkat kekerasan yang lebih rendah yang diperlihatkan dengan tingginya nilai penetrasi. Hal ini dikarenakan karet yang memiliki viskositas Mooney rendah memiliki sifat yang lebih lunak daripada karet dengan viskositas Mooney lebih tinggi. dibandingkan dengan persyaratan nilai penetrasi aspal polimer maka karet dengan viskositas Mooney terrendah yaitu yang dihasilkan dari penggilingan selama 24 menit memenuhi persyaratan nilai penetrasi aspal polimer.

Berdasarkan data nilai titik lembek dan penetrasi terlihat bahwa hanya ada dua jenis sampel yang memenuhi persyaratan yaitu aspal yang telah ditambahkan karet dengan viskositas Mooney 6,7 ML(1+4) $100^{\circ} \mathrm{C}$ yang diperoleh melalui penggilingan selama 24 menit dengan konsentrasi $5 \%$ dan $7 \%$. Apabila dikaitkan dengan nilai ekonomis tentu akan lebih ekonomis apabila berat karet yang ditambahkan adalah 5\%.

\section{KESIMPULAN DAN SARAN}

Berdasarkan penelitian ini maka dapat disimpulkan bahwa :

1. Depolimerisasi karet alam secara mekanis dapat menurunkan viskositas Mooney karet alam dan mempercepat kelarutan karet alam yang berupa padatan ke dalam aspal.

2. Depolimerisasi mekanis dalam open mill selama 24 menit menurunkan viskositas Mooney karet alam dari 58,7 menjadi $6,7 \mathrm{ML}(1+4) 100^{\circ} \mathrm{C}$ dan kecepatan pencampuran mempersingkat dari 660 menit menjadi hanya 50 menit.

3. Konsentrasi karet terdepolimerisasi (24 menit) dalam aspal yang memenuhi syarat titik lembek dan penetrasi aspal polimer adalah 5\% dan $7 \%$ namun secara ekonomis 5\% lebih menghemat biaya.

Untuk dapat diaplikasikan secara luas perlu dilakukan penelitian lebih lanjut tentang pengujian aspal karet ini secara lebih menyeluruh serta perhitungan teknoekonominya.

\section{DAFTAR PUSTAKA}

Badan Standarisasi Nasional. 2008. SNI 6749:2008, Standar Nasional Indonesia Spesifikasi Spesifikasi Lapis Tipis Aspal Pasir (Latasir). Badan Standarisasi Nasional, Jakarta. 
Badan Standarisasi Nasional. 1991. SNI 062434-1991, Standar Nasional Indonesia, Metode Pengujian Titik Lembek Aspal dan Ter. Badan Standarisasi Nasional, Jakarta

Badan Standarisasi Nasional. 1990. SNI.061903-1990, Standar Nasional Indonesia, Standar Indonesian Rubber (SIR). Badan Standarisasi Nasional, Jakarta

Bateman, L. 1963. The Chemistry and Physics of Rubber-Like Substances, Studies of The Natural Rubber Producer's Research Association. Mac Laren \& Sons LTD, London.

Departemen Pekerjaan Umum. 1999. Pedoman Penggunaan Aspal Karet Dalam Campuran Beraspal Secara Panas no 010/T/BM/1999. Yayasan Penerbit Pekerjaan Umum.
Direktorat Jendral Perkebunan. 2013. Produksi Karet. www.deptan.go.id diakses tanggal 7 Maret 2014.

International Rubber Study Group. 2013. Statitical Summary of World Rubber Situation. www.rubberstudy.com diakses tanggal 7 Maret 2014.

Prastanto, $\mathrm{H}$ dan A. A. Alfa. 2005. Pemanfaatan Karet Alam untuk Pembuatan Sealer/Dempul Pada Peralatan Pendingin. Prosiding seminar Nasional VIII, Jaringan Kerjasama Kimia 26 - 27 April : 480486

Suroso, T.W. 2007. Peningkatan Kinerja Campuran Beraspal dengan Karet Alam dan Karet Sintetis, Jurnal JalanJembatan 24(1) : 14-25 